\title{
Ebola treatment and prevention are not the only battles: understanding Ebola-related fear and stigma
}

\author{
Mohammad Karamouzian $^{1,2}$, Celestin Hategekimana ${ }^{1,3, *}$ \\ *Correspondence to: Celestin Hategekimana, Email: celekimana@gmail.com \\ Copyright: $\odot 2015$ by Kerman University of Medical Sciences \\ Citation: Karamouzian M, Hategekimana C. Ebola treatment and prevention are not \\ the only battles: understanding Ebola-related fear and stigma. Int J Health Policy Manag \\ 2015; 4: 55-56. doi: 10.15171/ijhpm.2014.128 \\ Received: 10 November 2014, Accepted: 29 November 2014, ePublished: 2 December 2014
}

\section{Dear Editor,}

Although Ebola Virus Disease (EVD) had already taken hundreds of lives in Liberia, Guinea, and Sierra Leone, it was only declared an 'Public Health Emergency of International Concern' in early August when the world started to panic from the possibility of EVD getting out of African borders - a fear that was spreading much faster than the virus itself $(1,2)$. The underlying causes of this fear, however, go far behind the uncertainties surrounding EVD's pathogenesis and could stem from the past (3). The western perception of associating West Africa with deadly diseases such as malaria, yellow fever and EVD, and representing the region as white man's grave is not just fueled by superstition or ignorance and has roots in history $(3,4)$. For instance, the yellow fever outbreak in Liberia in the 20s that led to the loss of several prominent American and British medical researchers and instructors, has left the West with painful memories of the region (3).

Regardless of past memories, while the transmission mechanism of Ebola is clear, there are irrational fears and overreactions globally. In the United States (U.S.) for example, school officials in New Jersey banned students coming from Rwanda (which is 1,700 miles away from the exposed region) from attending school unless after 21 days of quarantine (5). Similarly, some colleges in Texas rejected applications coming from Nigeria (6). Reports of flight suspensions to the area and imposing restrictions as well as visa denials for those coming from the region have also been ubiquitous (7). Unfortunately, these rejections and shunning behaviours have not only targeted some of the African nations, but have also affected western healthcare providers in close proximity with the patients in quarantine settings in U.S. hospitals (8).

On the other hand, fear also exists in West Africa where the local African communities may have concerns and mistrust about the spread of the disease and the western led investigations in their countries. This face of the fear has also deep roots in the past and can be elaborated upon by getting back to our history lesson of the former mentioned yellow fever outbreak in Liberia. When American research teams were sent to the region to collect samples and study the disease, they scared off the locals by using the routes used by European and West
African slave traders and white missionaries conquering the lands. Besides, while the members of that medical team did benefit from those samples in developing the yellow fever vaccine and later won a Nobel Prize, it seems that the medical research is still indebted to those communities for not building enough medical knowledge and capacity in the region $(3,4)$.

Therefore, these memories of exploitation of local residents and resources by western countries followed by the presence of western armies on the ground might have resulted in rising fear and driving conspiracy theories that EVD is being spread by the very western healthcare providers wearing those white biohazard suits and flooding into the communities (9). These perceptions could somehow explain the frequent cases of violent fatal attacks on healthcare providers and volunteers trying to prevent more casualties. For example, several aid workers were murdered in remote regions of Guinea and a group of volunteers were viciously attacked while trying to remove a dead body (10). While frustration and anger are plausible, attacks against both medical and humanitarian workers pose a great risk to local communities who depend on their programs for survival (11). Such fears have also led to stigmatization and victimization of EVD survivors $(12,13)$. Although they are provided with an EVD-free certificate, many survivors come back to their communities facing stigma, rejection, violence, and rumors blaming them for spreading the disease (12-14). They go back to their homes and find their jobs lost, and their properties (e.g. blankets, clothes, beds, and documents) destroyed (12-14).

Overall, structural shortages, such as poverty, insufficient education, and the political climate combined with cultural practices both inside and outside Africa, have affected attitudes, beliefs, and behaviors of the public towards the disease transmission $(15,16)$. Several lessons could be learned from de-stigmatizing strategies used to combat HIV-related stigma. Empowering communities as well as educational and prevention campaigns led by the local communities could help reduce the fear and stigma (9). Nonetheless, concerns of the public both inside and outside Africa should be heard, and their views and behaviours should be addressed; otherwise, mounting global response in turning the tide of the EVD epidemic would not reach its full potential.

\section{Ethical issues}

Not applicable.

\section{Competing interests}

Authors declare that they have no competing interests. 
Authors' contributions

Both authors contributed equally to the drafting and revising the manuscript and approved its final version.

Authors' affiliations

${ }^{1}$ School of Population and Public Health, Faculty of Medicine, University of British Columbia, Vancouver, British Columbia, Canada. ${ }^{2}$ Regional Knowledge Hub, and WHO Collaborating Center for HIV Surveillance, Institute for Futures Studies in Health, Kerman University of Medical Sciences, Kerman, Iran. ${ }^{3}$ Maternal, Newborn and Child Health in Rwanda (MNCHR), Kigali, Rwanda.

\section{References}

1. World Health Organization (WHO). Statement on the 1st meeting of the IHR Emergency Committee on the 2014 Ebola outbreak in West Africa [Internet]. 2014. Available from: http://www.who.int/ mediacentre/news/statements/2014/ebola-20140808/en/

2. World Health Organization (WHO). Ebola virus disease, West Africa - update 4 August 2014 [Internet]. 2014. Available from: http://www.afro.who.int/en/clusters-a-programmes/dpc/ epidemic-a-pandemic-alert-and-response/outbreak-news/4239ebola-virus-disease-west-africa-4-august-2014.html

3. Mitman G. Ebola in a Stew of Fear. N Engl J Med 2014; 371 : 1763-5. doi: 10.1056/nejmp1411244

4. Bayntun C, Houlihan C, Edmunds J. Ebola crisis: beliefs and behaviours warrant urgent attention. Lancet 2014; 384: 1424. doi: 10.1016/s0140-6736(14)61856-0

5. Chang D. African Students Scheduled to Start at NJ School Will Stay Home Past Waiting Period Amid Ebola Concerns [internet]. 2014. Available from: http://www.nbcphiladelphia.com/news/ local/Ebola-Fears-and-Arrival-of-2-African-Students-PromptParents-to-Keep-Kids-Home-From-Local-School--279718882. html

6. Mangan D. Texas college rejects Nigerian applicants, cites Ebola cases [internet]. 2014. Available from: http://www.cnbc. com/id/102087542\#.

7. Schnirring L. WHO pushes back against Ebola-related flight bans [internet]. 2014. Available from: http://www.cidrap.umn. edu/news-perspective/2014/08/who-pushes-back-againstebola-related-flight-bans

8. Hartocollis A, schweber N. Bellevue Employees Face Ebola at Work, and Stigma of It Everywhere [internet]. 2014. Available from: http://www.nytimes.com/2014/10/30/nyregion/bellevueworkers-worn-out-from-treating-ebola-patient-face-stigmaoutside-hospital.html?smid=fb-share\&_r=0

9. Davtyan M, Brown B, Folayan M. Addressing Ebola-related Stigma: Lessons Learned from HIVIAIDS. Glob Health Action 2014; 7: 26058. doi: 10.3402/gha.v7.26058

10. Wilson J. 8 killed in Guinea town over Ebola fears [internet]. 2014. Available from: http://www.cnn.com/2014/09/19/health/ ebola-guinea-killing/

11. Carmichael JL, Karamouzian M. Deadly professions: violent attacks against aid-workers and the health implications for local populations. Int J Health Policy Manag 2014; 2: 65-7. doi: 10.15171/ijhpm.2014.16

12. Gbandia S, Chen C. Ebola stigma adds burden as survivors face long recovery [internet]. 2014. Available from: http://www. bloomberg.com/news/2014-08-14/ebola-stigma-adds-burdenas-survivors-face-long-recovery.html

13. Aljazeera [home page on the internet]. Ebola survivors find lives disrupted. 2014. Available from: http://www. aljazeera.com/news/africa/2014/09/ebola-survivors-find-livesdisrupted-201492520265410815.html

14. World Health Organization (WHO). Life after Ebola has new meaning for two survivors now helping others [internet]. 2014. Available from: http://www.who.int/features/2014/life-after-ebola/ en/

15. Kunii O, Kita E, Shibuya K. [Epidemics and related cultural factors for Ebola hemorrhagic fever in Gabon]. Nihon Koshu Eisei Zasshi 2001; 48: 853-9. [In Japanese]

16. Leach M, Scoones I, Stirling A. Governing epidemics in an age of complexity: Narratives, politics and pathways to sustainability. Glob Environ Change 2010; 20: 369-77. doi: 10.1016/j. gloenvcha.2009.11.008 